\title{
Chemical Evidence for the Dawn of Life on Earth
}

\author{
Eva-Maria Krammer, ${ }^{\mathrm{A}}$ Sophie Bernad ${ }^{\mathrm{B}}$ G. Matthias Ullmann, ${ }^{\mathrm{A}}$ \\ Arthur Hickman, ${ }^{\mathrm{C}}$ and Pierre Sebban ${ }^{\mathrm{B}, \mathrm{D}, \mathrm{E}}$ \\ A Structural Biology/Bioinformatics, University of Bayreuth, Universitätsstr. 30, \\ BGI, D-95447 Bayreuth, Germany. \\ B Laboratoire de Chimie Physique, Université Paris-Sud 11/CNRS, \\ 91405 cedex, Orsay, France. \\ ${ }^{\mathrm{C}}$ Geological Survey of Western Australia, East Perth, WA 6004, Australia. \\ D Université des Sciences et des Technologies de Hanoi, 18 Hoang Quoc Viet, \\ Cau Giay, Hanoi, Vietnam. \\ ${ }^{\mathrm{E}}$ Corresponding author. Email: pierre.sebban@usth.edu.vn
}

\begin{abstract}
The dating of the dawn of life on Earth is a difficult task, requiring an accumulation of evidences from many different research fields. Here we shall summarize findings from the molecular scale (proteins) to cells and photosynthesis-relatedfossils (stromatolites from the early and the late Archaean Eon), which indicate that life emerged on Earth 4.2-3.8 Ga (i.e. 4.2-3.8 $\times 10^{9}$ years) ago. Among the data supporting this age, the isotopic and palaeontological fingerprints of photosynthesis provide some of the strongest evidence. The reason for this is that photosynthesis, carried out in particular by cyanobacteria, was responsible for massive changes to the Earth's environment, i.e. the oxygenation of the Earth's atmosphere and seawater, and the fixation of carbon from atmospheric $\mathrm{CO}_{2}$ in organic material. The possibility of a very early ( $>3.8 \mathrm{Ga}$ ago) appearance of complex autotrophic organisms, such as cyanobacteria, is a major change in our view of life's origins.
\end{abstract}

Manuscript received: 25 November 2010.

Manuscript accepted: 15 December 2010.

\section{Introduction}

From philosophic and scientific points of view, the origin and the development of life on Earth is certainly one of the most exciting topics to investigate, but also one of the most difficult. Indeed, it requires an effective and permanent multidisciplinary approach involving: chemistry, physics, biology, geology, and palaeontology.

From the start of a possible prebiotic chemistry $>4 \mathrm{Ga}$ $\left(4 \times 10^{9}\right.$ years) ago, when the conditions on Earth allowed it, to the presence of cells already endowed with a very complicated adenosine triphosphate (ATP)-producing metabolism, it seems likely that not more than 300 to 400 million years have passed. Whereas the earliest molecular steps leading to the dawn of life are still much debated, the evidences for the overall time frame for the evolution of life on Earth are becoming increasingly well established.

In this review we do not aim to be exhaustive in the description of the different prebiotic chemical steps that led to the development of the first, pre-LUCA (Last Universal Common Ancestor) proto-cells carrying a complicated metabolism. Instead, we shall take selected examples of molecular evolution and present evidence for the time frames of the most likely stages in the development of life on Earth. Among the supporting evidence, the isotopic and palaeontological fingerprints of photosynthesis are particularly convincing. We shall consider fossil stromatolites from the early and late Archaean eon as well as protein sequence comparisons between cyanobacteria and more primitive photosynthetic bacteria.
Since the work of Clair Patterson, ${ }^{[1]}$ who used an absolute dating method (based on $\mathrm{U} / \mathrm{Pb}$ disintegration) to estimate the age of a meteorite, it has been known that the Earth is $\sim 4.55 \mathrm{Ga}$ old. However, although the age of the Earth is now known quite precisely, the point at which life evolved is still in question and how life evolved is even more controversial. After the theory of spontaneous generation of life was rejected in the mid- to late19 th century, scientific debate on the origin of life could begin. A major breakthrough was achieved by A. Oparin, ${ }^{[2]}$ a Soviet biochemist, who proposed that a prerequisite for the emergence of complex life (cells) was the synthesis of organic compounds in large amounts on primitive Earth. It was a huge achievement of Oparin's to have obtained biochemical demonstrations of cell organization, metabolism, reproduction, and response to stimuli that could be understood in terms of physical and chemical mechanisms. He also had the great foresight to correlate the yield of prebiotic chemistry to the reducing capability of Earth's initial atmosphere. Thinking that autotrophy (which uses $\mathrm{CO}_{2}$ as the only source of carbon) was too complicated for the initial survival mode, he proposed fermentation and/or heterotrophy (using several organic compounds as the source of carbon) as the most likely first way of life for cells.

\section{Possible Chronology of the Development of Life on Earth Presence of Liquid Water}

After a period of strong bombardment by comets and meteorites, and intense volcanic activity, the temperature on Earth dropped below $100^{\circ} \mathrm{C}$, allowing the development of prebiotic chemistry. 
However, a prerequisite was the existence of liquid water, either at or near the surface of Earth. According to evaluations of the content of ${ }^{18} \mathrm{O}$ in ancient rocks (zircons) (which is indicative of the water-rock interaction at low temperature and of the presence of liquid water), it has been proposed ${ }^{[3,4]}$ that liquid water was present at $\sim 4.3-4.2 \mathrm{Ga}$ ago. This is significantly earlier than suggested ${ }^{[5]}$ from the evidence provided by basalt 'pillows' ( $\sim 3.8-3.9 \mathrm{Ga}$ ago $)$. Whether liquid water was mainly produced by volcanoes or brought from space by comets, its existence allowed life to evolve.

\section{The World of RNA and Nucleotides}

Before the appearance of the first proto-cells containing DNA, RNA and proteins, it is quite likely that RNA or simpler forms of RNAs (pre-RNAs) were selected to perform the roles now played by DNA, i.e. keeping the genetic information, and by proteins, i.e. acting as catalysts. ${ }^{[6-17]}$ This hypothesis, which is now generally accepted, is based on much solid, but indirect, evidence. ${ }^{[17,18]}$ This evidence includes the fact that, in present cells, DNA is used only to store genetic information, but RNA is an unavoidable intermediate as a messenger (mRNA) and directly involved as a catalyst ${ }^{[19,20]}$ in the synthesis of proteins. The experimental discovery of this catalytic role for RNA (therefore called ribozymes) was made by $\mathrm{T}$. Cech and S. Altman, for which they received the Nobel Prize of Chemistry in 1989. A final strong argument in favour of the RNA world comes from genome analysis of many microorganisms and some eukaryotes. When one searches for analogous proteins encountered in the three domains of life (Bacteria, Archaea, and Eukaryotes), and therefore present before the separation of the three domains, i.e. present in the LUCA, only 60 proteins are found. ${ }^{[21-25]}$ Interestingly, none are involved in the replication of DNA, i.e. they are neither helicases nor DNA polymerases. This is in strong support of RNA doing 'all' the jobs (i.e. storage of information and catalysis).

At the time of pre-cellular life (somewhere between $\sim 4.2$ and $3.8 \mathrm{Ga}$ ago), nucleotide-like molecules like ATP and nicotinamide adenine dinucleotide (NADH) were selected by evolution as universal energy and electron donor molecules, respectively. They are present in all three domains of life. Interestingly, ATP and NADH both contain the adenine base, which has been retained by evolution in the RNA and DNA of all organisms.

\section{Examples of Molecular Evolution}

\section{Complex III of the Respiratory Chain}

All organisms on Earth share the need to produce ATP for use in the metabolism of their cells. To achieve this, the three domains of life have retained since the LUCA period with the same kinds of processes and to some extent the same molecular compounds. Indeed, ATP synthase proteins, which are embedded in the intra-cytoplasmic membranes of bacteria and archaea or in the internal membrane of mitochondria from eukaryotes, use as a driving force an electrochemical proton gradient established across these membranes, most of the time coupled to an electron transfer chain. This was described by Peter Mitchell in his chemiosmotic theory, for which he received the Nobel Prize of Chemistry in 1978. ${ }^{[26]}$ This theory has been verified systematically in all types of organisms, and for whatever their type of survival, i.e. whether it be a respiratory or a photosynthetic electron transfer chain.

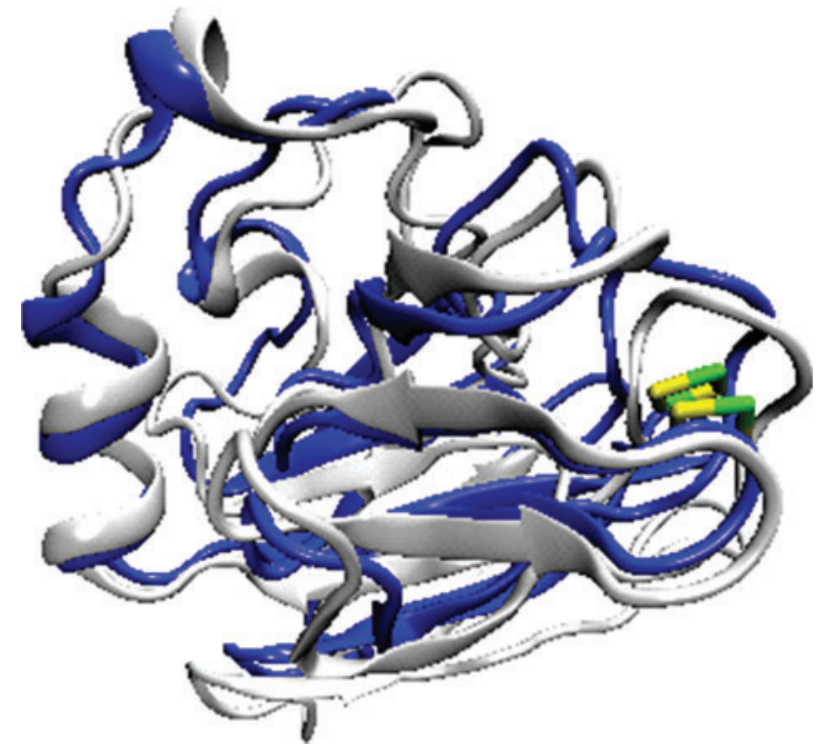

Fig. 1. Superimposition of the two 3D structures of the Rieske subunit of the cytochrome $\mathrm{bc}_{1}$ complex from Bos taurus (grey, pdb 1 rie $^{[27]}$ ) and from $R$. capsulatus (blue, pdb $1 \mathrm{zrt}^{[28]}$ ).

Let us take as examples the photosynthetic purple bacterium Rhodobacter (R.) capsulatus and the eukaryotic (respiratory) bovine Bos taurus. The electron transfer chain in the former is triggered by light, whereas in the latter, it is initiated by NADH. Despite their quite different appearances and distance at the evolutionary level, a similarity (among others) between the two organisms is that they both possess, as part of their electron transfer chains, a cytochrome bc 1 complex (also called complex III of the respiratory chain), which acts as a coenzyme Qcytochrome c oxidoreductase. This protein is quite big (MW $\sim 250 \times 10^{3} \mathrm{~g} \mathrm{~mol}^{-1}$ in mitochondria). Let us consider one of its subunits, the so-called Rieske protein that contains a cluster of $\mathrm{Fe}_{2} \mathrm{~S}_{2}$. This subunit consists of 191 and 196 amino acids in the bacterium and the cow, respectively. When these two sequences are compared (aligned), it is found that $\sim 40 \%$ of the amino acids are the same (at the same position) in both protein sequences. The probability that this has occurred by a fortuitous event, i.e. by independent mutations, is $\sim 10^{-100}$, i.e. close to 0 . It is, therefore, much more likely that the Rieske protein evolved at an early stage of life, and, because of its effectiveness, a large proportion of its amino acid sequence has been maintained even to species as apparently distantly related as a photosynthetic bacterium and a cow, with some mutations occurring since their common ancestor. As a consequence of this $40 \%$ sequence identity, remarkably the two protein subunits can nearly be superimposed. This is shown in Fig. 1 (using 1rie ${ }^{[27]}$ and $1 \mathrm{zrt}^{[28]}$ pdb code structures for Bos Taurus and R. capsulatus Fe-S subunits, respectively).

\section{Photosynthetic Reaction Centre}

In photosynthetic organisms, the reaction centre $(\mathrm{RC})$ protein plays a central role in converting the light excitation energy into chemical free energy through the establishment of a transmembrane charge separation. It is of interest to compare homologous subunits of the RC proteins from oxygen evolving organisms (OEO) (which extract electrons from water) and from more ancient organisms, which use various organic compounds as electron donors. The former organisms (predominantly 


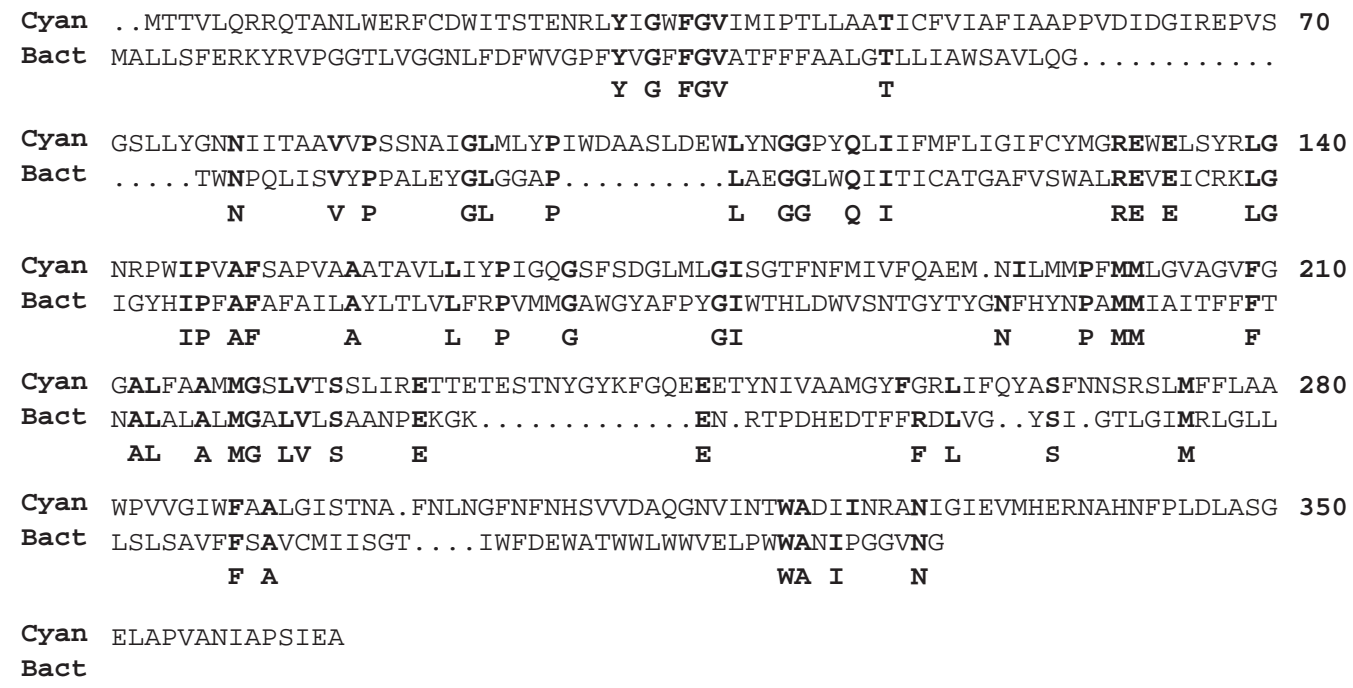

Fig. 2. Alignment of the sequences of the $\mathrm{D} 1$ and $\mathrm{L}$ protein subunit sequences from the cyanobacterium T. elongatus (Cyan) and from the bacterium R. sphaeroides (Bact), respectively, using the pHMM constructed in ref. [29]. The amino acids displayed below the sequences are conserved between the two proteins. The numbering refers to the T. elongatus sequence.

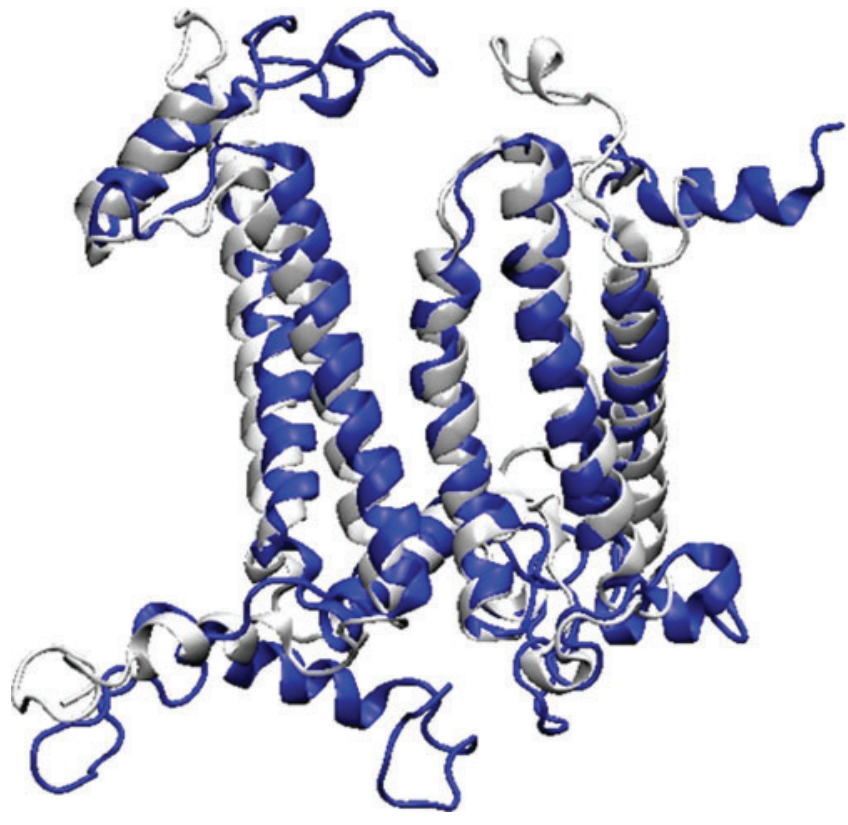

Fig. 3. Superimposition of the $\mathrm{L}$ protein from $R$. sphaeroides (blue, $\mathrm{pdb}$ 2J8C, $1.87 \AA$ resolution ${ }^{[35]}$ ) and of the D1 protein from T. elongatus (grey, pdb, 2AXT, $3 \AA$ resolution $\left.{ }^{[36]}\right)$. Despite the low $(\sim 20 \%)$ sequence identity, the secondary (and tertiary) structure is mainly conserved by evolution.

higher plants, algae, and cyanobacteria) possess two photosystems (PS1 and PS2) that act in series, and are mostly autotrophs. The latter (predominantly proteobacteria) are mostly heterotrophic. It is documented that the molecular ancestors of PS1 and PS2 are the RCs from green sulfur bacteria and purple non-sulfur bacteria, respectively. We shall compare below the sequence and the structure of one subunit of PS2-like RCs, i.e. the $\mathrm{Q}_{\mathrm{B}}$ binding protein (where $\mathrm{Q}_{\mathrm{B}}$ is the ultimate quinone electron acceptor bound to the protein), from OEOs and from purple non-sulfur bacteria. This particular protein is referred to as the 'D1 protein' in OEOs and as the 'L protein' in purple nonsulfur bacteria. As an example of an OEO, we have chosen
Thermosynechococcus (T.) elongatus, a cyanobacterium, and as an example of a purple non-sulfur bacterium we have chosen $R$. sphaeroides. Both organisms are prokaryotes.

Because cyanobacteria and purple non-sulfur bacteria are widely separated from an evolutionary perspective, the D1 protein sequence from $T$. elongatus only shares $\sim 20 \%$ amino acid sequence identity with the $\mathrm{L}$ protein from $R$. sphaeroides (see Fig. 2). This is not high and only about twice what would be expected $(\sim 10 \%)$ by comparing two random sequences from non-related proteins. The alignment of these two proteins is shown in Fig. 2. ${ }^{[29]}$

It is important to note that, because of the low percentage of sequence identity, a simple alignment realized only by comparing the two sequences (as achieved with readily available programs like CLUSTALW) was unreliable. ${ }^{[30,31]} \mathrm{We}$, therefore, aligned the D1 and L proteins using a general profile Hidden Markov Model (pHMM) ${ }^{[32,33]}$ which relies not only on a crude sequence alignment but also on a structural superposition of the D1 and L subunit sequences. ${ }^{[29,34]}$

The remarkable finding is that even with such a low percentage of sequence identity, the two proteins can almost be structurally superimposed (see Fig. 3).

We used here the $2 \mathrm{~J}_{8} \mathrm{C}^{[35]}$ and $2 \mathrm{AXT}^{[36]}$ pdb code structures for the $R$. sphaeroides L and T. elongatus D1 RC proteins, respectively. The reason for this structural similarity is the conservation of particular amino acids in crucial parts of the structure (see Fig. 2), leading to the same secondary structure (i.e. five transmembrane $\alpha$ helixes). This is a good example of where evolution has preserved a structural motif to maintain a useful function (energy conversion). ${ }^{[37,38]}$

\section{Crucial Importance of Cyanobacteria}

As discussed above, the D1 reaction centre protein of T. elongatus, a modern cyanobacterium, displays a low sequence identity with the functionally corresponding $\mathrm{L}$ protein of a photosynthetic purple bacterium. However, based on amino acid sequences of the D1 proteins, T. elongatus appears to show a much smaller evolutionary separation from higher photosynthetic organisms. Indeed, the D1 protein from T. elongatus possesses $85 \%$ identity with that of lettuce. 
Cyanobacteria are key organisms at the origin of a main turning point of the atmosphere and life on Earth, i.e. the increase in the level of oxygen on Earth. Cyanobacteria were the first organisms to extract electrons from water (abundant on Earth since at least $\sim 4.2-4.0 \mathrm{Ga}$ ago), rather than from organic compounds or $\mathrm{H}_{2} \mathrm{~S}$, as do green sulfur bacteria. The energy price to pay for achieving this is very high since the redox potential of the $\mathrm{H}_{2} \mathrm{O} / \mathrm{O}_{2}$ redox couple is very positive $(\sim 0.82 \mathrm{~V})$. Cyanobacteria paved the way for their photosynthetic descendants, thanks to the association of both PS2 and PS1, which work in series to absorb enough energy (two photons) to split the water molecule.

The consequence of the evolution of the water-splitting ability of the cyanobacteria was dramatic for the future of Earth. Indeed, progressively, the oxygen (actually a waste product of $\mathrm{H}_{2} \mathrm{O}$ oxidation from the perspective of the cyanobacteria) released by this reaction rose into the atmosphere, converting its initial either inert or reducing environment into a strongly oxygenated, oxidising one. Although it seems certain that the level of free $\mathrm{O}_{2}$ in the atmosphere was similar to that of today by $\sim 2-1.5 \mathrm{Ga}$ ago (from dating the iron oxides of ancient oceans ${ }^{[5]}$ ) there is still much debate about when exactly cyanobacteria started their 'job' of releasing oxygen. ${ }^{[39-44]}$

Very recently, the appearance of cyanobacteria was suggested $^{[45]}$ not to have occurred before $\sim 3 \mathrm{Ga}$ or even later. However, a more recent publication ${ }^{[46]}$ strongly suggests that oxygen was already present in deep oceans $3.46 \mathrm{Ga}$ ago, necessarily making the origin of cyanobacteria much earlier. We shall see below that this is consistent with isotopic and palaeontologic observations.

\section{Evidence for the Existence of Cells $>3.5 \mathrm{Ga}$ Ago} Isotopic Data

Carbon possesses two stable isotopes, ${ }^{12} \mathrm{C}$ and ${ }^{13} \mathrm{C}$, and consequently atmospheric $\mathrm{CO}_{2}$ is composed of ${ }^{12} \mathrm{CO}_{2}$ and ${ }^{13} \mathrm{CO}_{2}$. ${ }^{12} \mathrm{CO}_{2}$ and ${ }^{13} \mathrm{CO}_{2}$ are trapped to different degrees in photosynthetic organisms and in limestone. This provides a very solid and useful tool to probe for the presence of photosynthesis by revealing its fingerprint in ancient rocks.

Photosynthesis is the process by which vegetal organisms synthesize carbohydrate using the energy they gain from the absorption of light. In oxygenic photosynthesis, water is used as an electron donor, according to Eqn (1):

$$
6 \mathrm{CO}_{2}+12 \mathrm{H}_{2} \mathrm{O} \rightarrow 6\left(\mathrm{CH}_{2} \mathrm{O}\right)+6 \mathrm{O}_{2}+6 \mathrm{H}_{2} \mathrm{O}
$$

In anoxygenic photosynthesis, water is replaced by reduced compounds such as $\mathrm{H}_{2} \mathrm{~S}, \mathrm{H}_{2}$, malate, succinate, butyrate, or reduced metal ions as $\mathrm{Fe}^{2+}$. For example, when $\mathrm{H}_{2} \mathrm{~S}$ is used, sulfur is released, as shown in Eqn (2):

$$
6 \mathrm{CO}_{2}+12 \mathrm{H}_{2} \mathrm{~S} \rightarrow 6\left(\mathrm{CH}_{2} \mathrm{O}\right)+6 \mathrm{H}_{2} \mathrm{O}+12 \mathrm{~S}
$$

In both cases, $\mathrm{CO}_{2}$ is captured by an enzyme called RubisCO (ribulose bisphosphate carboxylase) which also catalyzes the first reactions associated with $\mathrm{CO}_{2}$ reduction. Because it is lighter than ${ }^{13} \mathrm{CO}_{2},{ }^{12} \mathrm{CO}_{2}$ is captured slightly more efficiently (by a diffusion process), i.e. it collides slightly more frequently with RubisCO and is therefore more often trapped. The sugars produced by photosynthetic organisms (oxygenic and anoxygenic) will thus contain a slightly higher $(\sim 1.8 \%){ }^{12} \mathrm{C}$ content than that present in the $\mathrm{CO}_{2}$ of the atmosphere. ${ }^{[47]}$
In the case of the isotopic contents of carbon in limestone the situation is opposite. Indeed, when $\mathrm{CO}_{2}$ dissolves in sea water, it is initially converted into bicarbonate $\left(\mathrm{HCO}_{3}^{-}\right)$, which then associates with dissolved calcium ions to produce calcium carbonate $\left(\mathrm{CaCO}_{3}\right)$, which forms the limestone deposited in oceans. In this case, the heavier ${ }^{13} \mathrm{CO}_{2}$ is preferentially captured because it sediments more rapidly and the limestone is enriched in ${ }^{13} \mathrm{C}$ by $\sim 0.7 \%$. ${ }^{[47]}$ Thus, the carbon isotopic enrichments of photosynthetic organisms and limestone are the reverse of one another. The relative ratios of ${ }^{13} \mathrm{C}$ and ${ }^{12} \mathrm{C}$ in limestone and organic carbon in rocks dated from the same period will hence be a signature of the existence of photosynthesis at that time. This is generally quantified using the value of $\delta^{13} \mathrm{C}$, which is defined as the difference in the percentage ratios ${ }^{13} \mathrm{C} /{ }^{12} \mathrm{C}$ for organic carbon and limestone (both measured mass spectrometry techniques). Based on the values of the percentage enrichments ${ }^{13} \mathrm{C}$ in photosynthetic organisms $(-1.8 \%)$ and limestone $(+0.7 \%)$ given above, one would expect a value of $\delta^{13} \mathrm{C}$ of approximately $-2.5 \%$ (i.e. $-1.8-(+0.7)$ ). This $\delta^{13} \mathrm{C}$ value is observed in present or recent rocks, therefore validating this method. But what is remarkable is that when more and more ancient rocks are dated and screened, the presence of photosynthesis (and therefore of cells endowed of complex metabolism able to produce ATP) is established at $>3.5 \mathrm{Ga}$ ago. As we see below, geological and palaeontological investigations are fully consistent with and reinforce these observations.

\section{Data from Stromatolites}

Stromatolites (from greek strôma, carpet, and lithos, stone) are either fossilized or living mats of limestones arranged in layers of cyanobacteria and filamentous bacteria (see Fig. 4). $\mathrm{CO}_{2}$, which is trapped in the surrounding water, leads to $\mathrm{CaCO}_{3}$ precipitation that settles and hardens to form characteristic structures, most of the time in 'domes' or 'cones'. $\mathrm{CaCO}_{3}$ can sometimes be replaced by other minerals near saturation.

For this reason hot spring stromatolites tend to consist of silica. Living stromatolites can be observed in different places, among them Yellowstone National Park (USA) and Shark Bay (Western Australia) (see Fig. 5).

Interestingly, ancient (Archaean) stromatolite-like fossils (SLF) can also be observed; the best preserved being in Western Australia, in the Pilbara region (see Fig. 6).

We shall consider the stromatolite-like fossils, dated at $2.72 \mathrm{Ga}$ ago (Fortescue Group) ${ }^{[48]}$ and $\sim 3.5 \mathrm{Ga}$ ago ('North Pole' and 'Dawn of Life'). ${ }^{[49]}$ Examples that can be observed in the Fortescue Group (dome-like) and in the Dawn of Life trail (cone-like) are shown in Fig. 7.

Two main non-biological processes may mimic or contribute to similar geological structures: the chemical precipitation of sedimentary rocks and/or the physical deformation of the rocks. Therefore, a crucial question that arises from these observations is: are these structures of biogenic origin?

In the case of the 2.72 Ga SLF (see Fig. 7), it seems very likely to be the case. Two main arguments support this conclusion. The first one is morphological, based on the very similar appearance of the domes in the Fortescue Group and the living ones (see Fig. 5). The second definitive argument has recently been provided by the analysis of the microstructures of the rocks of the SLF in the Fortescue Group. They clearly show formations of 'organic globules' associated with microcrystals of $\mathrm{CaCO}_{3}$, a combination that is remarkably similar to the organo-mineral building blocks of modern stromatolites. ${ }^{[50]}$ 


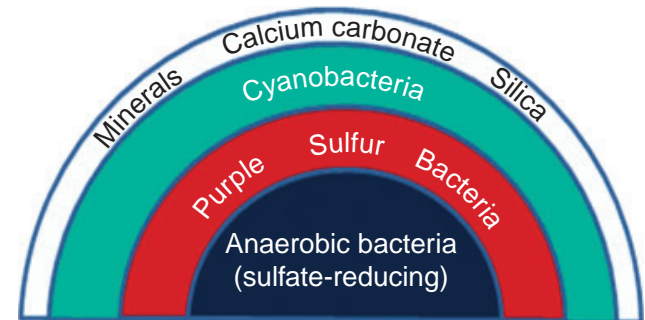

Fig. 4. Schematic cross-sectional view of the different layers of the upper lamina of stromatolites.
Now let us consider the SLF dated as $\sim 3.5$ Ga ago (see Fig. 7, right). Although at present there is no absolute proof of their biological origin, the combination of all available evidence produces an overwhelming probability that they have not been produced by physical processes, or simply by abiogenic chemical precipitation. The first line of evidence comes from morphological analysis. The cone shape of SLF in Fig. 7 cannot be due to chemical precipitations since they would produce regular forms and not, as observed here, thicker layers on the top and thinner layers on the sides. Furthermore, sediment depositions would neither produce sharp sides nor cones, but rather crests. One of the most convincing morphological arguments is given

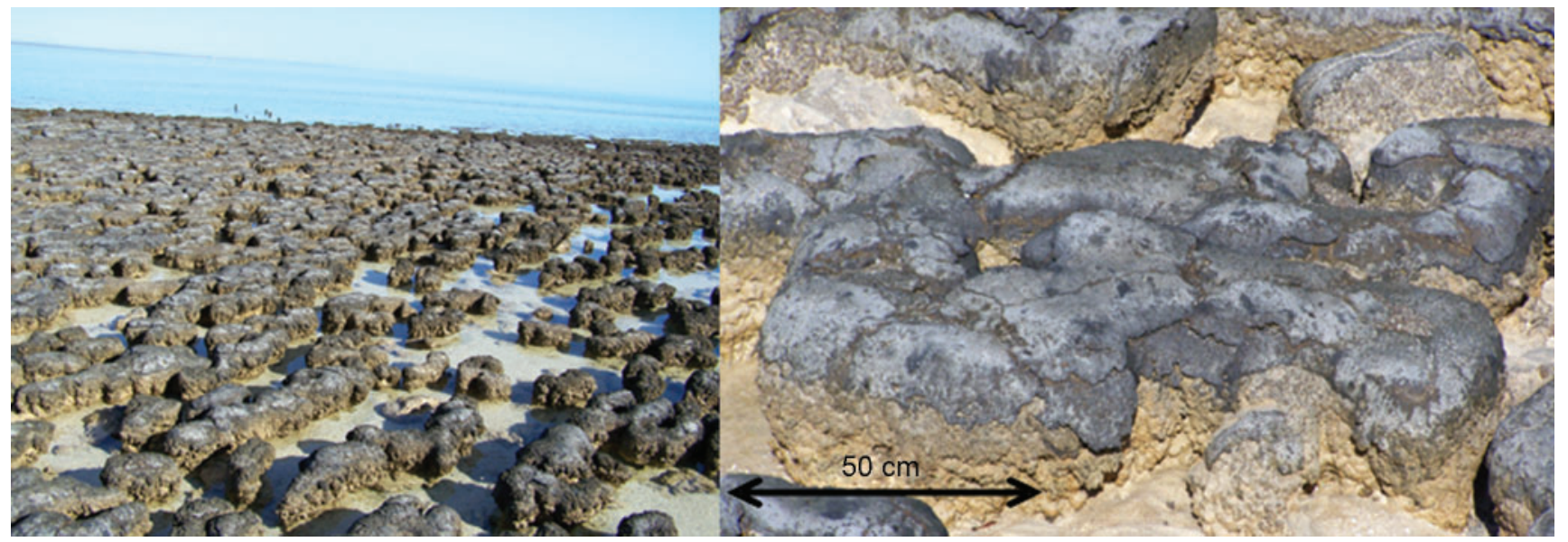

Fig. 5. Stromatolites observed in Shark Bay (Western Australia). Left: low tidal general view; right: focus on one mat system.

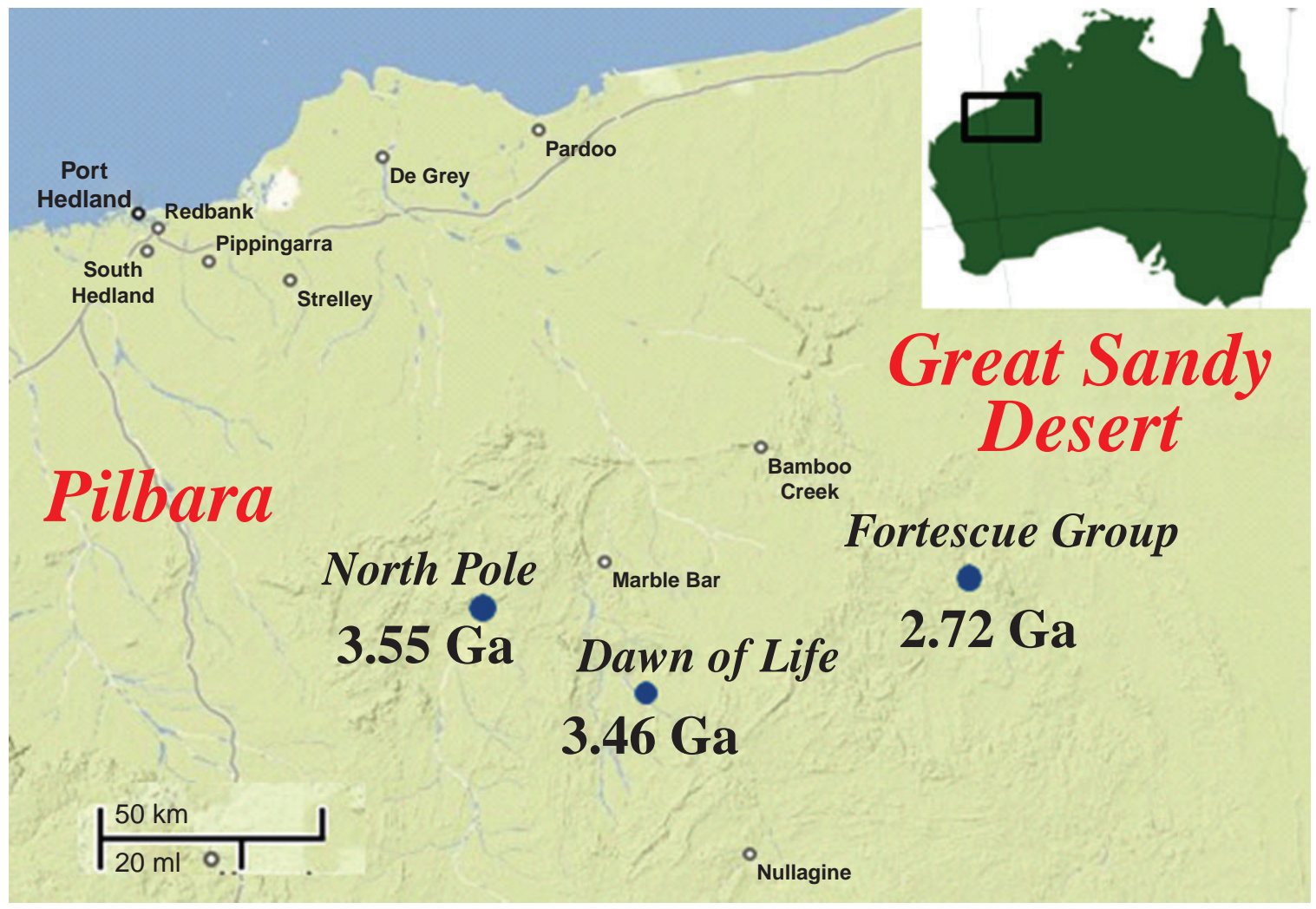

Fig. 6. Pilbara region (Western Australia), where Archean fossil stromatolites are situated. 
by the presence of cones arranged in an 'egg-carton' pattern ${ }^{[51]}$ and branching columns (see Fig. 8).

These shapes are characteristic of bacterial growth, and very likely rule out formation by means such as soft-sediment folding. Moreover, the shapes of the cones of the SLF found in the Strelley Pool Formation at the Dawn of Life trail and at many other localities in the east Pilbara region demonstrate a limited range of variation, a feature consistent with biologically produced structures.

Allwood et al. ${ }^{[52]}$ have recently shown that a chemical precipitation would produce a much broader variety of shapes. These authors have also suggested that there is a close correlation between the shapes of the SLF and the sedimentary environment where they are found in the Pilbara. This also strongly favours a biological origin. In addition, is the fact that some of the $3.5 \mathrm{Ga}$ SLF have identical shapes to those of $2.72 \mathrm{Ga}$, that are accepted by palaeontologists as being of biological origin. Last but not least, there are no known examples of non-biogenic internally complex domes, steepsided cones and branching columns in Nature, particularly in the Phanerozoic sedimentary record. All these arguments are fully consistent with the isotopic evidence of the presence of photosynthetic organisms at $3.5 \mathrm{Ga}$ ago or even before.

\section{Conclusions}

Until very recently, the presence of molecular oxygen on Earth (produced by cyanobacteria) was considered to be notable only at $2 \mathrm{Ga}$ ago or later. ${ }^{[53-55]}$ The recent finding of haematite crystals in 3.46 Ga marine sedimentary rocks has modified this

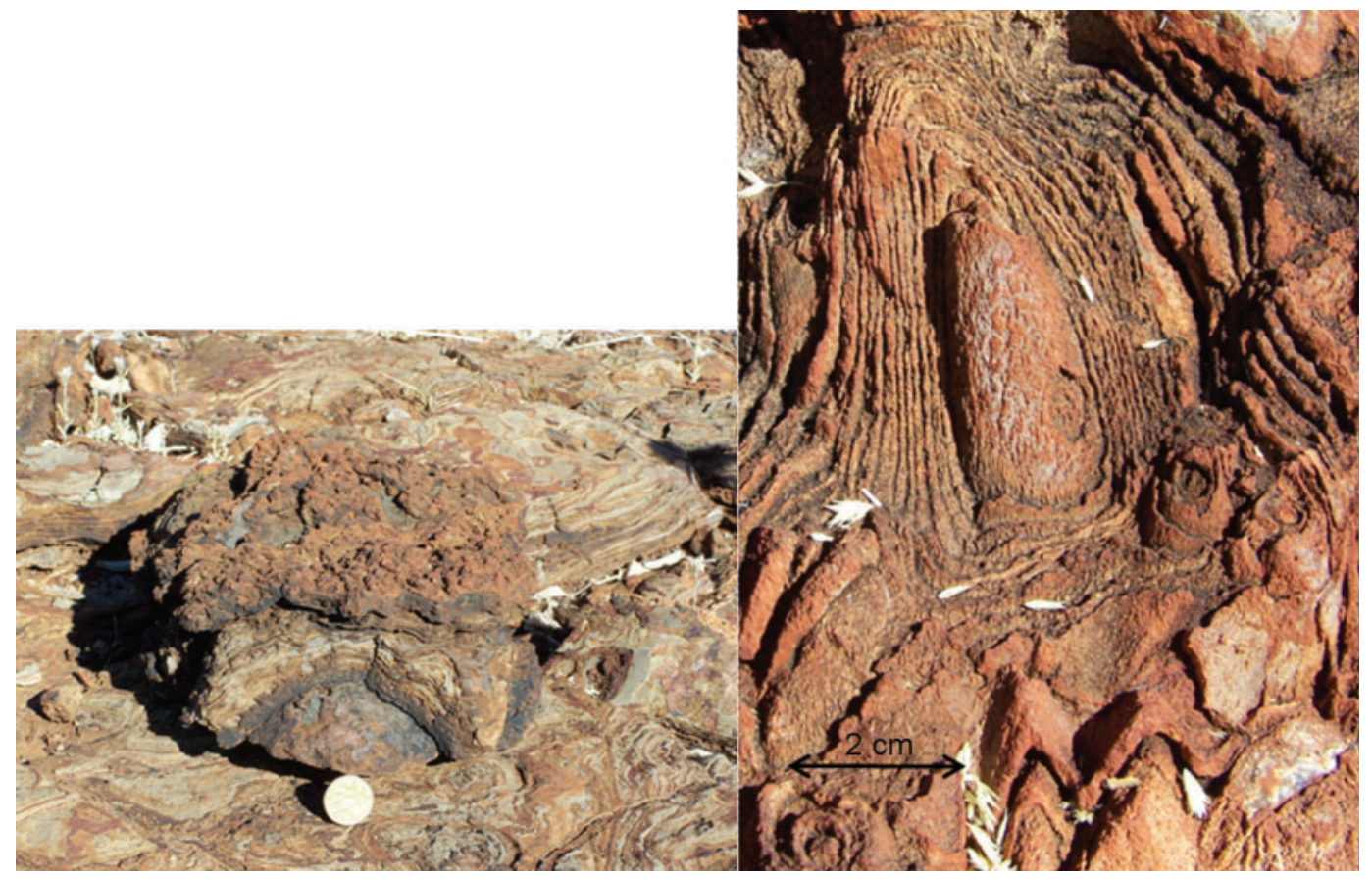

Fig. 7. Fossil stromatolites found in the Pilbara region (Western Australia); left: fossil stromatolites 'dome' shape found in the Fortescue Group and dated at $\sim 2.72 \mathrm{Ga}$ ago; right: cone shaped stromatolites observed at the Dawn of Life trail, Pilbara (Western Australia) dated at $\sim 3.46 \mathrm{Ga}$ ago.

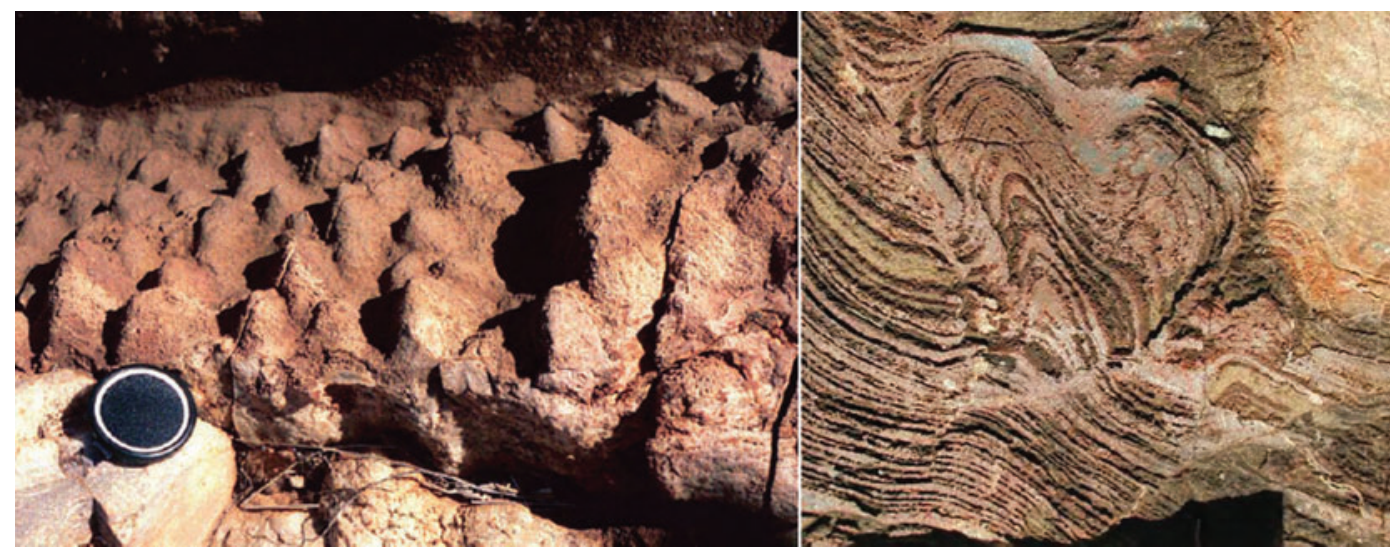

Fig. 8 (Left panel) 'Egg-carton' and (right panel) 'branching columns' stromatolites discovered in carbonate rocks in the Strelley Pool Chert of the Kelly Group at the Trendall locality in the eastern Pilbara (1997). They provide the most convincing evidence to date that these structures (3.42 Ga ago) are of biogenic origin. Image provided with the courtesy of the Geological Survey of Western Australia (GSWA). 
view. ${ }^{[45]}$ These authors have proposed that this finding reflects the presence of large volumes of oxygenated seawater at $3.46 \mathrm{Ga}$ ago. Since it is difficult to imagine any production of molecular oxygen without photosynthesis, and probably without cyanobacteria, this pushes back the start of Earth's oxygenation to the early Archaean and probably the appearance of cyanobacteriainhabiting stromatolites well before $<3.5 \mathrm{Ga}$ ago. Taken together with the recent suggestion that liquid water (and therefore prebiotic chemistry) would have been present at 4.3-4.2 Ga ago, the rise of life on Earth is likely to have occurred 4.2-3.8 Ga ago, earlier than previously thought. It is remarkable that complex autotrophic life must have existed at a time where until very recently only heterotrophic life forms were considered to have been able to be present on Earth. The extremely fast apparition of a complex life being produced by random chemical processes governed by natural selection as proposed by Darwin, is one of the most fascinating thing that Nature displays to humankind's eyes.

\section{Acknowledgements}

We would like to thank Dr Kath Grey (GSWA) for her appreciated help in providing very useful information about the Dawn of Life Trail and more generally about stromatolites, and Professors R. Burne and A. Glikson in helping to detect the 'good spots' at the Dawn of Life Trail. A. Hickman publishes with permission of the Executive Director of the Geological Survey of Western Australia. Dr. R. J. Clarke is very warmly thanked for very helpful discussions, for his suggestions, remarks and for correcting the manuscript.

\section{References}

[1] C. A. Patterson, Geochim. Cosmochim. Acta 1956, 10, 230. doi:10.1016/0016-7037(56)90036-9

[2] A. I. Oparin, The Origin of Life 1924 (Moscow Worker Publisher: Moscow).

[3] S. J. Mojzsis, T. M. Harrison, R. T. Pidgeon, Nature 2001, 409, 178. doi: $10.1038 / 35051557$

[4] J. W. Valley, A. J. Cavosie, B. Fu, W. H. Peck, S. A. Wilde, Science 2006, 312, 1139. doi:10.1126/SCIENCE.1125301

[5] D. Rumble, in Chemical Evolution across Space \& Time 2008, ACS Symp. Ser. Vol. 981, Ch. 14, pp. 261-281 (Eds L. Zaikowski, J. M. Friedrich) (American Chemical Society: Washington, DC).

[6] G. F. Joyce, Nature 2002, 418, 214. doi:10.1038/418214A

[7] A. Korostelev, H. F. Noller, Trends Biochem. Sci. 2007, 32, 434. doi:10.1016/J.TIBS.2007.08.002

[8] H. F. Noller, Nature 1991, 353, 302. doi:10.1038/353302A0

[9] A. D. Ellington, M. P. Robertson, J. Bull, Science 1997, 276, 546. doi:10.1126/SCIENCE.276.5312.546

[10] D. L. Robertson, G. F. Joyce, Nature 1990, 344, 467. doi:10.1038/ 344467A0

[11] M. P. Robertson, S. L. Miller, Science 1995, 268, 702. doi:10.1126/ SCIENCE. 7732378

[12] M. P. Robertson, W. G. Scott, Science 2007, 315, 1549. doi:10.1126/ SCIENCE. 1136231

[13] G. J. Connell, M. Yarus, Science 1994, 264, 1137. doi:10.1126/ SCIENCE.7513905

[14] M. Illangasekare, G. Sanchez, T. Nickles, M. Yarus, Science 1995, 267, 643. doi:10.1126/SCIENCE.7530860

[15] M. Yarus, Curr. Opin. Chem. Biol. 1999, 3, 260. doi:10.1016/S13675931(99)80041-6

[16] M. Yarus, Nature 2005, 438, 40. doi:10.1038/438040A

[17] C. de Duve, Proc. Natl. Acad. Sci. USA 1987, 84, 8253. doi:10.1073/ PNAS.84.23.8253

[18] C. de Duve, Singularités: Jalons sur les chemins de la vie 2005 (Odile Jacob: Paris).

[19] T. R. Cech, Science 2000, 289, 878. doi:10.1126/SCIENCE.289. 5481.878

[20] T. R. Cech, Gene 1993, 135, 33. doi:10.1016/0378-1119(93)90046-6
[21] C. Brochier-Armanet, S. Gribaldo, P. Forterre, Biol. Direct 2008, 3, 54. doi:10.1186/1745-6150-3-54

[22] P. Forterre, Microbes de l'enfer 2007 (Belin-Pour la Science: Paris).

[23] P. Forterre, D. Gadelle, Nucleic Acids Res. 2009, 37, 679. doi:10.1093/ NAR/GKP032

[24] S. Gribaldo, A. M. Poole, V. Daubin, P. Forterre, C. BrochierArmanet, Nat. Rev. Microbiol. 2010, 8, 743. doi:10.1038/ NRMICRO2426

[25] J. Keller, N. Leulliot, N. Soler, B. Collinet, R. Vincentelli, P. Foterre, H. Van Tilbeurgh, Protein Sci. 2009, 18, 850.

[26] P. Mitchell, J. Moyle, Nature 1965, 208, 147. doi:10.1038/208147A0

[27] S. Iwata, M. Saynovits, T. A. Link, H. Michel, Structure 1996, 4, 567. doi:10.1016/S0969-2126(96)00062-7

[28] E. A. Berry, L.-S. Huang, L. K. Saechao, N. G. Pon, M. ValkovaValchanova, F. Daldal, Photosynth. Res. 2004, 81, 251. doi:10.1023/ B:PRES.0000036888.18223.0E

[29] E.-M. Krammer, P. Sebban, G. M. Ullmann, Biochemistry 2009, 48, 1230. doi:10.1021/BI802033K

[30] B. Rost, Protein Eng. 1999, 12, 85. doi:10.1093/PROTEIN/12.2.85

[31] J. M. Sauder, J. W. Arthur, R. L. Dunbrack, Proteins 2000, 40, 6. doi:10.1002/(SICI)1097-0134(20000701)40:1<6::AID-PROT30> 3.0.CO;2-7

[32] S. R. Eddy, Curr. Opin. Struct. Biol. 1996, 6, 361. doi:10.1016/S0959440X(96)80056-X

[33] S. R. Eddy, Bioinformatics 1998, 14, 755. doi:10.1093/ BIOINFORMATICS/14.9.755

[34] E.-M. Krammer, M. S. Till, P. Sebban, G. M. Ullmann, J. Mol. Biol. 2009, 388, 631. doi:10.1016/J.JMB.2009.03.020

[35] J. Koepke, E.-M. Krammer, A. R. Klingen, P. Sebban, G. M. Ullmann, G. Fritsch, J. Mol. Biol. 2007, 371, 396. doi:10.1016/J.JMB.2007. 04.082

[36] B. Loll, J. Kern, W. Saenger, A. Zouni, J. Biesiadka, Nature 2005, 438, 1040. doi:10.1038/NATURE04224

[37] J. P. Allen, J. C. Williams, FEBS Lett. 1998, 438, 5. doi:10.1016/ S0014-5793(98)01245-9

[38] A. W. Rutherford, P. Faller, Philos. Trans. R. Soc. Lond. B Biol. Sci. 2003, 358, 245. doi:10.1098/RSTB.2002.1186

[39] R. E. Blankenship, Trends Plant Sci. 2001, 6, 4. doi:10.1016/S13601385(00)01831-8

[40] R. E. Blankenship, Plant Physiol. 2010, 154, 434. doi:10.1104/ PP.110.161687

[41] R. E. Blankenship, H. Hartman, Trends Biochem. Sci. 1998, 23, 94. doi:10.1016/S0968-0004(98)01186-4

[42] J. Raymond, Trends Microbiol. 2008, 16, 41.

[43] J. Raymond, R. E. Blankenship, Chem. Rev. 2008, 252, 377.

[44] J. Raymond, O. Zhaxybayeva, J. P. Gogarten, R. E. Blankenship, Philos. Trans. R. Soc. Lond. B Biol. Sci. 2003, 358, 223. doi:10.1098/ RSTB.2002.1181

[45] B. Rasmussen, I. R. Fletcher, J. J. Brocks, M. R. Kilburn, Nature 2008 , 455, 1101. doi:10.1038/NATURE07381

[46] M. Hoashi, D. C. Bevacqua, T. Otake, Y. Watanabe, A. H. Hickman, S. Utsunomiya, H. Ohmoto, Nat. Geosci. 2009, 2, 301. doi:10.1038/ NGEO465

[47] W. J. Schopf, Science 1993, 260, 640. doi:10.1126/SCIENCE.260. 5108.640

[48] A. H. Knoll, Life on a Young Planet 2003 (Princeton University Press: Princeton, NJ)

[49] D. R. Lowe, Nature 1980, 284, 441. doi:10.1038/284441A0

[50] K. Lepot, K. Benzerara, G. E. Brown, P. Philippot, Nat. Geosci. 2008, 1, 118. doi:10.1038/NGEO107

[51] H. J. Hofmann, K. Grey, A. H. Hickman, R. I. Thorpe, Geol. Soc. Am. Bull. 1999, 111, 1256. doi:10.1130/0016-7606(1999)111<1256: OOGCSI $>2.3 . \mathrm{CO} ; 2$

[52] A. C. Allwood, M. R. Walter, B. S. Kamber, C. P. Marshall, I. W. Burch, Nature 2006, 441, 714. doi:10.1038/NATURE04764

[53] R. P. Reid, N. P. James, I. G. Macintyre, C. P. Dupraz, R. V. Burne, Facies 2003, 49, 299.

[54] W. J. Schopf, Photosynth. Res. 2010, in press.

[55] J. Farquhar, A. L. Zerkle, A. Bekker, Photosynth. Res. 2010, in press. 